\title{
EFFECTS OF GAMMA IRRADIATION ON THE PHYSICAL PROPERTIES OF PAni.MWCNT/PMMA FILMS
}

\author{
Tariq J. Alwan \\ Al Mustansiriyah University, College of Education, Physics Department, Baghdad, Iraq \\ e-mail: tariqjaffer2000@yahoo.com
}

(Received February 05, 2019; in final form -September 3, 2019)

\begin{abstract}
In this study, the effect of gamma irradiation on PAni.MWCNT/PMMA films was investigated, for using them as dosimeters. In particular, the effects of gamma irradiation on the morphological characteristics, structure, electrical conductivity, and some optical properties of PAni.MWCNT/PMMA films were studied before and after irradiation. Samples were fabricated by casting method, obtained by using PAni.MWCNT with 3.8 wt\% PMMA weight ratio, and exposed to a $\left(\mathrm{Cs}^{137}\right)$ gamma-radiation source at different dose rates $(0,2.7$, and $4.8 \mathrm{kGy})$ at room temperature. The morphological characteristics of the PAni.MWCNT/PMMA films were examined through scanning electron microscopy. X-ray diffraction analysis revealed the effect of irradiation on the structure and average crystallite size of the films. The FTIR was carried out for samples within the range $600-4000 \mathrm{~cm}^{-1}$ to study the functional groups of PAni.MWCNT/PMMA films, and the presence of characteristic bonds of PAni.MWCNT/PMMA films were observed using FTIR spectroscopy technique. Electrical conductivity analysis showed that the conductivity of the unirradiated film of $2.02 \times 10^{-8} \mathrm{~S}_{\mathrm{cm}} \mathrm{cm}^{-1}$ increased to $2.77 \times 10^{-8} \mathrm{~S} . \mathrm{cm}^{-1}$ after the samples were exposed to $4.8 \mathrm{kGy}$. The absorption spectra of the PAni.MWCNT/PMMA films were also obtained. Spectral analysis demonstrated that optical transition was an allowed direct transition, and the optical band gap increased as the radiation dose increased. The observed changes in these physical properties suggested that PAni.MWCNT/PMMA films may be used as an effective material for gamma radiation dosimeters at room temperature.
\end{abstract}

Key words: polyaniline (PAni), PAni.MWCNT/PMMA, conducting Polymer, PMMA.

DOI: https://doi.org/10.30970/jps.23.3710

PACS number(s): 78.30.Jw, 42.70.Jk, 42.70.Jk

\section{INTRODUCTION}

With the use of polymers in scientific and technological fields, the properties of these polymers in relation to their uses should be investigated. Studies have described their physical properties, such as transparency, flexibility, conductivity, and resistance to different environmental conditions, and many different physical properties are required for the scientific applications of these polymers. They can be improved on the basis of their physical properties to eliminate their disadvantages [1]. Polymers were used as insulators until 1977 because of the presence of covalent bonds characterized by their inability to exhibit electrical and thermal conductivity [2]. But after 1977, conjugated conducting polymers were discovered; this type of polymers possesses alternating single $(\sigma)$ and double $(\pi)$ bonds along the main polymer chain. Thus, conjugated double bonds allow electric flow [3]. The electrical conductivity of these polymers can be changed by doping to about $\left(10^{-12}-10^{4}\right)$ $\mathrm{S} \cdot \mathrm{cm}^{-1}[2]$, and this process involves oxidation or reduction [4]. The discovery of conductive polymers has made a great development in the electronic industry for a large number of important applications, such as sensors, transistors, light-emitting diodes, solar cells, and other devices [5]. Polyaniline (PAni) is one of the most famous conductive polymers because of its easy preparation, high conductivity, and good environmental stability; one of the most interesting features of PAni is its ability to switch between electrically insulating and conducting states via doping [6]. PAni is often mixed with conventional polymers, such as Poly(methyl methacrylate) (PMMA), Polystyrene (PS), and Polyethylene oxide (PEO), because of its poor mechanical properties [7].

PMMA is a member of a family of polymers which chemists call acrylates, but the rest of the world calls acrylics. Pure, atactic poly(methyl methacrylate) PMMA is an amorphous plastic with a high surface gloss, high brilliance; it has good mechanical strength, acceptable chemical resistance, and extremely good weather resistance. PMMA can be produced using a variety of polymerization mechanisms [8]. PAni is one of the polymers used to measure dosages in radiation dosimetry based on changes in electrical or optical properties under the influence of radiation [9]. Radiation methods are largely used for polymerization and polymer modification because a polymer subjected to irradiation undergoes structural changes; consequently, these methods can be exploited to obtain new features or to improve the polymer performance [10]. The main effect of radiation on polymers is the degradation or crosslinking of their molecules. Through these two effects, the main changes 
in the properties of polymers occur. Degradation leads to a decrease in molecular weight and the formation of gaseous products, such as $\mathrm{CO}_{2}$, hydrogen gas, methane, and carbon dioxide. Crosslinking is equivalent to degradation, that is, crosslinking is a process by which two radicals or molecules of the same type are combined (dimerization); crosslinking is the reverse of degradation in which chain bonding causes an increase in molecular weight [11]. In mixing polymers with nanoparticles that have different shapes, such as spheres, rods, tubes, fibers, wires, and other shapes, shape and size play an important role in determining the ability to obtain a homogeneous mixture of polymers and nanoparticles with advanced properties compared with mixtures containing materials with microparticles [12]. Polymer-carbon nanotubes (CNTs) are a composite of a polymer with CNTs that have unique properties that cannot be obtained for each material alone. These composites show potential for electronic applications because of the formation of conducting polymer-CNT networks [13-14]. The effect of MWCNT content on the conductivity of PAni-MWCNT composites has been studied. The conductivity of PAni composites usually increases with the content of MWCNTs [14].

In this study, PAni.MWCNTs/PMMA films were produced by casting and subsequently irradiated with various doses of gamma rays. The influence of radiation on the morphological characteristics, structure, electrical and optical properties, and feasible use of PAni.MWCNTs/PMMA films as gamma dosimeters was investigated.

\section{EXPERIMENTAL}

PAni.MWCNT/PMMA films were prepared by casting method. PAni.MWCNT was fabricated through the in situ oxidative polymerisation of aniline/MWCNT in acidic media in accordance with the method previously described by Jabbar 2018 [15]. For the preparation of PAni.MWCNT solution, $0.05 \mathrm{~g}$ of PAni.MWCNT powder was dissolved in $5 \mathrm{ml}$ of $\mathrm{CHC1}_{3}$ and stirred for 3 h. Afterward, $3.8 \%$ weight ratio of PMMA was added to prepare a PAni.MWCNT/PMMA solution. The mixture was placed in a stirrer for $2 \mathrm{~h}$ to obtain a homogeneous solution. This solution was then poured into a flat glass plate and dried at room temperature. The samples were irradiated by various doses of gamma rays $(0$, 2.7 and $4.8 \mathrm{kGy}$ ) at room temperature by using $\mathrm{Cs}^{137}$ as a gamma source. Infrared analysis in the wave number range of $600-4000 \mathrm{~cm}^{-1}$ was conducted using a SIDCO England series FT-IR spectrometer. The morphological characteristics and surface topography of the films were imaged using a scanning electron microscope. The structure of these samples was investigated by using Philips Xray diffraction (XRD) diffractometers. The optical measurements of the PAni.MWCNT/PMMA films were performed on the basis of transmittance and absorbance spectra at 300-900 nm by using a UV-VIS spectrophotometer type SHIMADZU UV-VIS 1600/1700 series.

\section{RESULTS AND DISCUSSION}

The SEM images were used to study the morphological characteristics of PAni.MWCNT/PMMA films before and after irradiation. Fig. 1 shows the PAni.MWCNT/PMMA images before and after irradiation with the gamma dose of $4.8 \mathrm{kGy}$. From the SEM image of the PAni.MWCNT/PMMA films before irradiation one can note a homogeneous diffusion of MWCNTs in PAni, and PMMA also showed the coating of these MWCNTs with a polymeric material, leading to an increase in the diameter of MWCNTs. The SEM image also illustrates an irregular network formed between MWCNTs, thereby improving the properties of the samples. This observation was consistent with the findings of Kondawar et al 2012 [16] about the effect of MWCNTs on the properties of PAni. The SEM image of the PAni.MWCNT/PMMA films subjected to irradiation revealed that the morphological characteristics of the films slightly changed after irradiation. Any defects, such as the breakage of MWCNT after irradiation, were absent from the irradiated films, indicating that irradiation did not remarkably affect the morphological characteristics of PAni.MWCNT/PMMA films. This finding was consistent with those described in other studies, such as Bosworth 2012 [17] and Augustine et al. 2015 [18], suggesting that irradiation did not influence the morphological characteristics of polymeric materials.

Figure 2 shows the XRD patterns of PAni.MWCNT/PMMA films prepared by casting before and after irradiation with different gamma doses. The XRD of the PAni.MWCNT/PMMA films before irradiation showed only one broad, weak, and low-intensity peak at $2 \theta=16.6^{\circ}$, indicating that the prepared film had an amorphous structure. This result is similar to that observed in PAni and PMMA composites reported by other groups [19], [20]. The X-ray spectra of the samples after irradiation showed that the number of peaks increased, suggesting that the films had a polycrystalline structure. In the sample irradiated with $2.7 \mathrm{kGy}$, the sharpness and intensity of the peak at $2 \theta=16.6^{\circ}$ increased, and three new peaks formed. A broad peak appeared at $2 \theta=19^{\circ}$, and two other sharp peaks were detected at $2 \theta=33.5^{\circ}$ and $44^{\circ}$. These two sharp peaks quickly disappeared when the radiation dose increased to $4.8 \mathrm{kGy}$, and they were then replaced by four new sharp peaks at $2 \theta=$ $28^{\circ}, 28.5^{\circ}, 29.5^{\circ}$, and $31^{\circ}$ and a broad peak at $2 \theta=$ $22.5^{\circ}$. This result demonstrated that gamma irradiation enhanced the structure of the PAni.MWCNT/PMMA films. The average crystallite size (C.S.) of the samples can be calculated from the X-ray spectrum through the full-width at half maximum (FWHM) method (Scherrer relation) [21].

$$
C . S .=\frac{D \lambda}{\Delta \beta \cos \theta}
$$

where $\Delta \beta$ is the FWHM of the XRD peak at a diffraction angle $\theta, \mathrm{D}$ is Scherrer's constant $\mathrm{D}=1$, and $\lambda$ is the $\mathrm{X}$-ray 
wavelength. The C.S. of PAni.MWCNT/PMMA films before irradiation was about $8.49 \AA$, which increased to $43.27 \AA$ when the sample was irradiated with $4.8 \mathrm{kGy}$ (Table). Hence, the crystallization state of the samples was enhanced by irradiation with gamma rays.

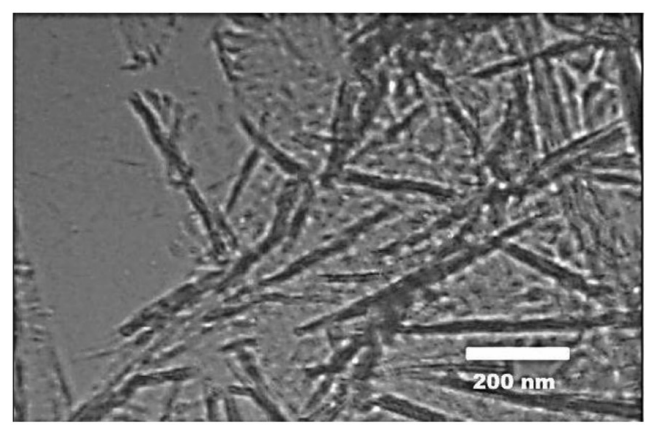

Non-irradiated

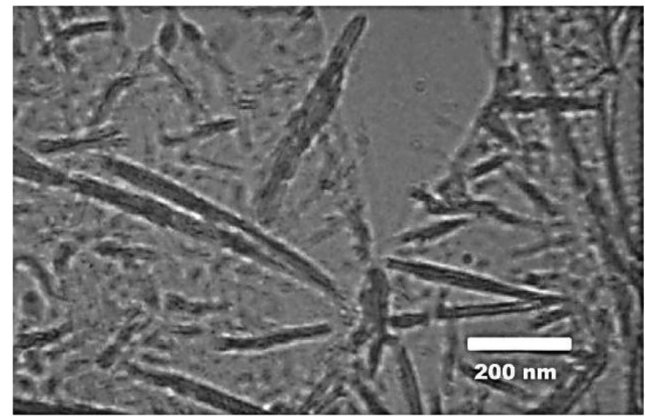

$4.8 \mathrm{kGy}$

Fig. 1. The SEM images of the PAni.MWCNT/PMMA before and after gamma irradiation.

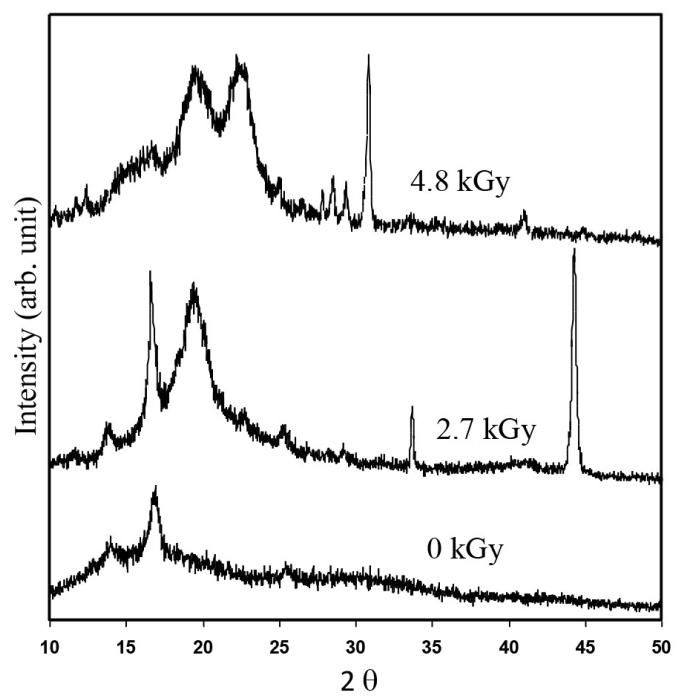

Fig. 2. X-ray diffraction of the PAni.MWCNT/PMMA films before and after gamma irradiation.

The FTIR spectrum of the PAni.MWCNT/PMMA films before and after irradiation by different gamma ray doses is shown in Fig. 3. The main characteristic peaks of the samples appeared in the composite and were as- signed as follows: the $\mathrm{C}=\mathrm{C}$ stretching modes for quinoid and benzoid units occurred at $1487 \mathrm{~cm}^{-1}$; the bands at 1292 and $1396 \mathrm{~cm}^{-1}$ were attributed to the $\mathrm{C}-\mathrm{N}$ stretching mode of the benzoid unit; and the peak at $771 \mathrm{~cm}^{-1}$ was associated with $\mathrm{C}-\mathrm{C}$ and $\mathrm{C}-\mathrm{H}$ of the benzoid unit [22]. The band assigned to the carbonyl group $\mathrm{C}=\mathrm{O}$ appeared at $1755 \mathrm{~cm}^{-1}$, and the bands at $2990 \mathrm{~cm}^{-1}$ were attributed to the aliphatic group $\mathrm{C}-\mathrm{H}$ [23]. The characteristic bands and their arrangements for the composite before irradiation were similar to those after irradiation, suggesting that irradiation did not affect the chemical bonds of PAni.MWCNT/PMMA films [22].

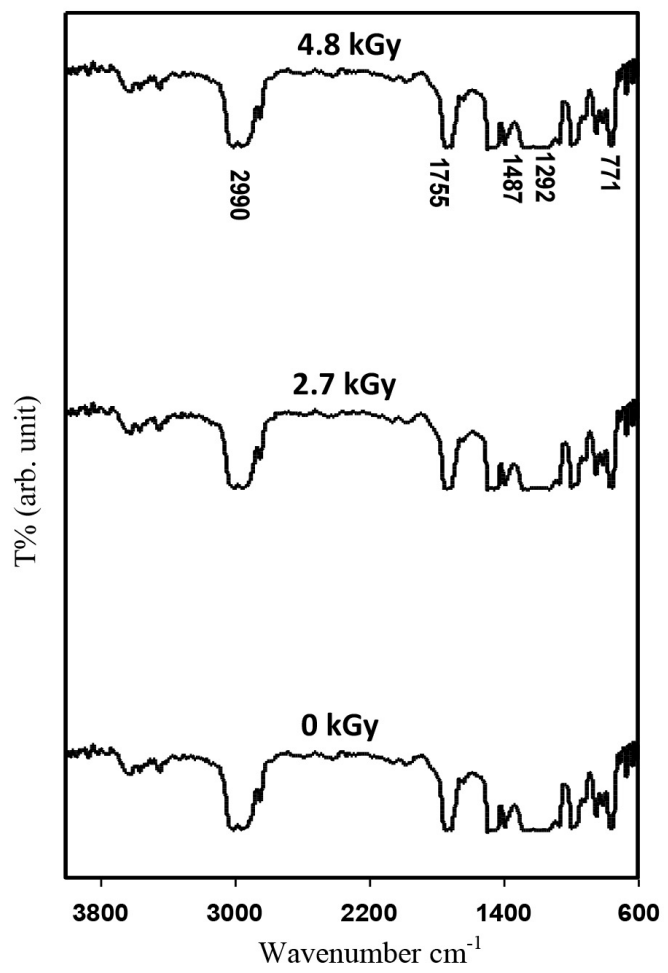

Fig. 3. FTIR spectra of the PAni.MWCNT/PMMA films before and after gamma irradiation.

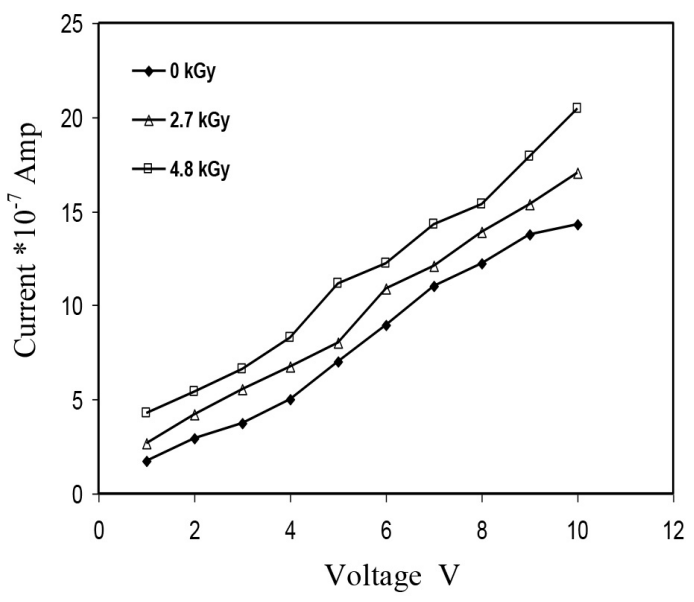

Fig. 4. The (current-voltage) curves for PAni.MWCNT/ PMMA films before and after gamma irradiation. 
The D.C. conductivity of the PAni.MWCNT/PMMA films was studied by plotting the current as a function of the applied voltage at different radiation doses (Fig. 4). The electrical conductivity of the PAni.MWCNT/PMMA films was measured (Table). The results revealed that their electrical conductivity increased as the irradiation dose increased. When the dose was $0 \mathrm{kGy}$, the electrical conductivity was $2.02 \times 10^{-8}$ $\mathrm{S} \cdot \mathrm{m}^{-1}$, which increased to $2.77 \times 10^{-8} \mathrm{~S} \cdot \mathrm{m}^{-1}$ at $4.8 \mathrm{kG}$. This increase in conductivity may be due to the formation of polarons created at the defects site, which moves towards the polymer backbone. This implies that the radiation induced degradation becomes effective and hence increases the motion of free radicals, thereby increasing the conductivity. This increase in conductivity after irradiation is also supported by the improvement of the structure of PAni.MWCNT/PMMA films subjected to irradiation, which increased the carrier mobility and enhanced the conductivity. This finding was consistent with those observed by Sonkawade et al. 2010 [24] and Meftah et al. 2014 [25], who emphasized that irradiation by gamma ray increases the conductivity of conductive polymers.

The absorption spectra of the PAni.MWCNT/PMMA films are shown in Fig. 5(I). The absorption spectra of the unirradiated films and the films irradiated with $2.7 \mathrm{kGy}$ decreased with the wavelength. This behavior changed at $4.8 \mathrm{kGy}$ and the spectra increased with the wavelength. On the other hand, the absorption values of the films decreased with irradiation in all of the wavelengths used in the measurement. These results were attributed to the structural change that occurred with irradiation [26].

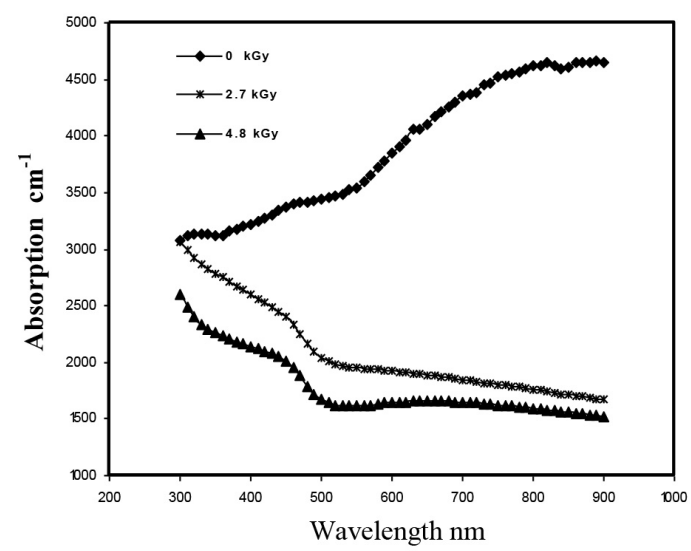

Fig. 5. The variation of Absorption spectra with wavelength for PAni.MWCNT/PMMA films before and after gamma irradiation.

Absorption spectra, which are the direct and possibly the simplest method for probing the band structure of films, are used to determine the energy gap $\left(E_{g}\right)$ calculated from the following equation:

$$
\alpha h \nu=B\left(h \nu-E_{g}\right)^{r}
$$

where $\alpha h \nu$ is the absorption coefficient, $B$ is a constant, and $r$ is an index that can be supposed to have values of $3,2,3 / 2$, and $1 / 2$ corresponding to forbidden indirect transition, indirect allowed transition, forbidden direct transition, and allowed direct transition, respectively, depending on the type of electronic transition responsible for absorption $[27,28]$.

The type of electronic transitions can be determined by the dependence on absorption coefficients; in particular, direct transitions occur when $\alpha h \nu>10^{4} \mathrm{~cm}^{-1}$, whereas indirect transitions occur at $\alpha h \nu<10^{4} \mathrm{~cm}^{-1}$ [29].

The present PAni.MWCNT/PMMA films exhibited direct allowed transition, and $E_{g}$ of the films was determined from the straight line plot of $(\alpha h \nu)^{2}$ as a function of photon energy (Fig. 6). The direct allowed $E_{g}$ of the

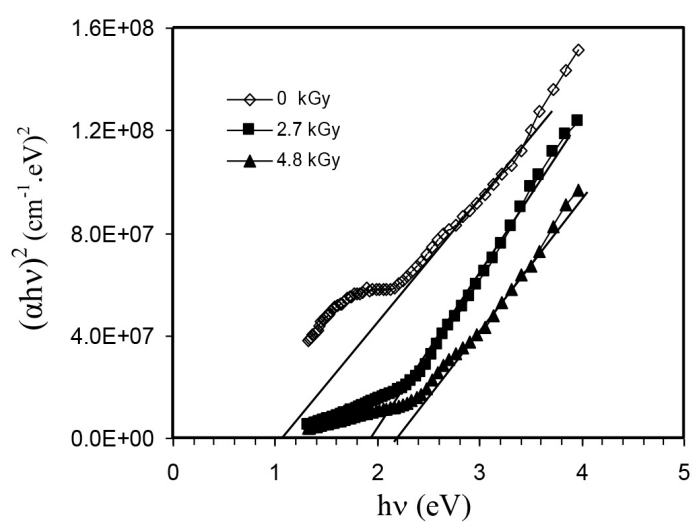

Fig. 6. The variation of $\left((\alpha h \nu)^{2}\right.$ with $(h \nu)$ for PAni.MWCNT/PMMA films before and after gamma irradiation.

PAni.MWCNT/PMMA films increased strongly from $1.1 \mathrm{eV}$ for the unirradiated film to $2.4 \mathrm{eV}$ for the film irradiated with $4.7 \mathrm{kGy}$. The variation in $E_{g}$ with irradiation is summarized in Table. This result was consistent with previous findings [30].

\begin{tabular}{|c|c|c|c|}
\hline Dose & Crystalite, Size $\AA$ & $\sigma, \mathrm{S} \cdot \mathrm{cm}^{-1}$ & $E_{g}, \mathrm{eV}$ \\
\hline $0 \mathrm{kGy}$ & 8.49 & $2.02 \times 10^{-8}$ & 1.1 \\
\hline $2.7 \mathrm{kGy}$ & 39.8 & $2.45 \times 10^{-8}$ & 1.95 \\
\hline $4.8 \mathrm{kGy}$ & 43.27 & $2.77 \times 10^{-8}$ & 2.3 \\
\hline
\end{tabular}

Table. Some physical parameters of PAni.MWCNT/PMMA films.

\section{CONCLUSIONS}

A well-homogenized polyaniline can be successfully prepared with MWCNTs mixed with PMMA through a casting method. Different doses of gamma radiation improve the structural, optical, and electrical properties of the films by increasing the average crystalline size, $E_{g}$, and the electrical conductivity of the prepared films, but such doses do not affect the morphological characteristics of the prepared films. Our results indicate that PAni.MWCNT/PMMA films may be used as a material for measuring specific gamma radiation doses of $0,2.7$, and $4.8 \mathrm{kGy}$ at room temperature. 
[1] J. E. Mark, Physical Properties of Polymers Handbook, 2nd ed. (Springer, New York, 2007); https://doi.org/ 10.1007/978-0-387-69002-5.

[2] H. Shirakawa, E. J. Louis, A. G. Maccdiarmid, C. K. Chiong, A. J. Heeger, J. Chem. Soc. Chem. Commun. 16, 578 (1977); https://doi.org/10.1039/C39770000578.

[3] G. G. Wallace, G. M. Spinks, P. R. Teasdale, Conductive Electroactive Polymers, 2nd ed. (CRC Press LLC, USA, 2003).

[4] L. Dai, Intelligent Macromolecules for Smart Devices from Materials Synthesis to Device Applications (Springer, London, 2004); https://doi.org/10.1007/ b97517.

[5] B. J. Schwartz, Annu. Rev. Phys. Chem. 54,141(2003); https://doi.org/10.1146/annurev.physchem. 54 . 011002.103811 .

[6] Zh. A. Boeva, V. G. Sergeyev, Polymer Sci. C 56, 144 (2014); https://doi.org/10.1134/S1811238214010032.

[7] Tariq J. Alwan, Abed Al-Khaliq S. Jabbar, Jalal S. Bdaiwi, in Proceedings of the IIER International Conference (Crete-Greece, 2018), p. 14.

[8] M. Stickler, T. Rhein, Ullmann's Encyclopedia of Industrial Chemistry. Polymethacrylates, 5th ed., edited by B. Elvers, S. Hawkins, G. Schultz (VHS, New York, 1992); https://doi.org/10.1002/14356007.a21_ 473. pub2.

[9] J. M. G. Laranjeira, H. J. Khourya, W. M. de Azevedob, E. A. de Vasconcelosc, E. F. da Silva Jr, Mater. Characterization 50, 127 (2003); https://doi.org/10.1016/ S1044-5803(03) 00079-2.

[10] M. Marianim et al., J. Radioanal. Nucl. Chem. 286, 625 (2010); https://doi.org/10.1007/s10967-010-0778-z.

[11] G. Spadaro, S. Alessi, C. Dispenza, in Applications of Ionizing Radiation in Materials Processing. Vol. 1, edited by Y. Sun, and A. G. Chmielewski, (Institute of Nuclear Chemistry and Technology, Warszawa, 2017), p. 167.

[12] A. Khosla, Electrochem. Soc. Interface, 21(3-4), 67 (2012); https://doi.org/10.1149/2.F04123-4if.

[13] A. I. Gopalan, K. P. Lee, P. Santhosh, K. S. Kim, Y. C. Nho, Comp. Sci. Technol. 67, 900, (2006); https: //doi.org/10.1016/j.compscitech.2006.02.036.
[14] S. G. Bachhav, S. G. Patil, J. Mater. Sci. 5, 90 (2015); https://doi.org/10.5923/j.materials.20150504.03.

[15] A. S. Jabbar, M. Sc. Thesis (Al-Mustansiriyah University, College of Education, Physics Department, Iraq, 2018).

[16] S. B. Kondawar, M. D. Deshpande, S. P. Agrawal, Int. J. Comp. Mater. 2, 32 (2012); https://doi.org/10.5923/ j.cmaterials.20120203.03.

[17] L. A. Bosworth, A. Gibb, S. Downes, J. Polymer Sci. B 50, 870(2012); https://doi.org/10.1002/polb.23072.

[18] R. Augustine, A. Saha, V. P. Jayachandran, S. Thomas, N. Kalarikkal, Int. J. Polym. Mater. Polym. Biomater. 64, 526 (2015); https://doi.org/10.1080/00914037. 2014.977900

[19] G. Chakraborty, K. Gupta, D. Rana, A. K. Meikap, Adv. Nat. Sci. Nanosci. Nanotechnol. 3, 035015 (2012); https: //doi.org/doi:10.1088/2043-6262/3/3/035015.

[20] S. Ghatak et al., J. Appl. Polymer Sci. 119, 1016 (2011); https://doi.org/10.1002/app.31962.

[21] B. D. Cullity, S. R. Stock, Elements of X-ray Diffraction, 3th ed. (Prentice-Hall, United States of America, 2001).

[22] M. Nagaraja et al., J. Electron. Mater. 41, 1882 (2012); https://doi.org/10.1007/s11664-012-2004-y.

[23] A. K. Tomar, S. Mahendia, S. Kumar, Adv. Appl. Sci. Res. 2, 327 (2011).

[24] R. G. Sonkawadeet al., Indian J. Pure Appl. Phys. 48, 453 (2010).

[25] A. M. Meftah , E. Gharibshahi, N. Soltani, W. M. Mat Yunus, E. Saion, Polymers 6, 2435 (2014); https://doi. org/10.3390/polym6092435.

[26] A. Ashour, M. A. Kaid, N. Z. El-Sayed, A. A. Ibrahim, Appl. Surf. Sci. 252, 7844 (2006); https://doi.org/10. 1016/j.apsusc. 2005.09.048.

[27] J. Tauc, Amorphous and Liquid Semiconductors (Plenum Press, New York, 1979).

[28] S. M. Sze, Semiconductor Devices Physics and Technology, 3th ed. (John Wiley \& Sons, Inc., Canada, 2007).

[29] B. Thangaraju, P. Kalianna, Cryst. Res. Techon. 35, 71 (2000); https://doi.org/10.1002/(SICI) 1521-4079(200001) 35:1<71: :AID-CRAT71>3.0.CO;2-U.

[30] O. Karabulut et al., Süleyman Demirel Üniversitesi J. Sci. 7, 112 (2012).

\title{
ВПЛИВ ГАММА-ОПРОМІНЕННЯ НА ФІЗИЧНІ ВЛАСТИВОСТІ ПЛІВОК PAni.MWCNT/PMMA
}

\author{
Тарік Дж. Альван \\ Університет Аль-Мустансірія, Багдад, Ірак
}

\begin{abstract}
У цій праці досліджено вплив гамма-опромінення на плівки PAni.MWCNT/PMMA для використання їх як дозиметрів. Зокрема, вивчено вплив гамма-опромінення на морфологічні характеристики, структуpy, електропровідність та деякі оптичні властивості плівок PAni.MWCNT/PMMA до та після опромінення. Зразки виготовляли методом лиття, отриманим за допомогою PAni.MWCNT з масовим співвідношенням 3.8 мас.\% ПММА та піддавали впливу джерела гамма-випромінювання $\left(\mathrm{Cs}^{137}\right)$ за різних величин дози $(0,2.7$, і 4.8 кГр) при кімнатній температурі. Морфологічні характеристики плівок PAni.MWCNT/PMMA досліджували за допомогою сканувальної електронної мікроскопії. Рентґенодифракційний аналіз виявив вплив опромінення на структуру та середній розмір кристалітів плівок. FTIR було проведено для зразків у межах
\end{abstract}


TARIQ J. ALWAN

600-4000 $\mathrm{cm}^{-1}$ для вивчення функціональних груп плівок PAni.MWCNT/PMMA та наявність характерних зв'язків плівок PAni.MWCNT/PMMA спостерігали за допомогою методики спектроскопї̈ FTIR. Аналіз електропровідності показав, що електропровідність неопроміненої плівки становить $2.02 \times 10^{-8} \mathrm{~S} \cdot \mathrm{cm}^{-1}$ збільшилася до $2.77 \times 10^{-8} \mathrm{~S} \cdot \mathrm{cm}^{-1}$ після того, як зразки зазнали впливу $4.8 \mathrm{k}$ р. Було також отримано спектри поглинання плівок PAni.MWCNT/PMMA. Спектральний аналіз показав, що оптичний перехід був дозволеним прямим переходом, а розрив оптичної смуги збільшувався зі збільшенням дози випромінювання. Спостережувані зміни цих фізичних властивостей дозволяють припустити, що плівки PAni.MWCNT/PMMA можна використовувати як ефективний матеріал для дозиметрів гамма-випромінювання за кімнатної температури. 